\title{
A NEW DIMENSION IN THE SECURITY OF POLAND
}

\begin{abstract}
At the end of the 1980s, a process of systemic transformation began in Poland and other Central and Eastern European countries. That international situation prompted an opportunity to build new national security structures within Poland. At that time, Tadeusz Mazowiecki became the Prime Minister of the Polish government. The Ministry of Foreign Affairs was managed by Krzysztof Skubiszewski for over four years, and during that time, Skubiszewski had many successes. A new quality of the Polish security policy was created. The Third Polish Republic has regulated relations with its nearest neighbors, although they are not friendly with everyone. Today, none of Poland's neighbors question the country's borders. Since 1999, Poland has been recognized as a member of the North Atlantic Treaty Organization (NATO). From the very beginning, NATO was an important component of the Polish security policy. In 2004, Poland joined the European Union (EU), which opened new possibilities for the country. The aim of this article is to present the changes in the security policy of the Third Republic since the political transition in 1989 to Poland's accession to NATO and the EU. To achieve this, the author analyzed selected materials and presented his own assessments. New directions of the security policy of the Third Polish Republic are highlighted.
\end{abstract}

Keywords: diplomacy, security, political transformation of Poland, foreign policy, security policy.

\section{INTRODUCTION}

The problem of security has a special meaning for Poland. In the history of the Polish Country in the last three centuries, it is easy to see negligence in the sphere of defense and the resulting consequences (Kuźniar, 2008). When analyzing the problems of Poland's security, it is worth stressing that the skillful foreign policy is of great importance in this respect. The security of the state is largely determined by alliances, coalitions or other systems of connections, which were not always properly understood by representatives of the political class.

After the end of Second World War and the beginning of the process of European integration, the military force ceased to dominate. Political elites in the western countries sought new solutions to security problems. In Central and Eastern Europe, cooperation within international organizations was preferred (Zenderowski, Koziński, 2010). The growing hostility between the western and eastern blocs after the World War II and the fears of the Western European countries before the Soviet Union led to intensification of

\footnotetext{
${ }^{1}$ Henryk Ćwięk, Prof. DSc, PhD, Jan Długosz University in Częstochowa, Faculty of Social Sciences, Department of Security Sciences, ul. Waszyngtona 4/8, 42-200 Częstochowa; e-mail: h.cwiek@interia.pl. ORCID 0000-0001-9779-9119.
} 
activities within the framework of the project of a United Europe. An important task was to create a collective security system on the Old Continent (Stokwiszewski, 2014). Polish policy towards international organizations, both now and in the past, is an important element of its foreign policy( Madera, 2003).

1989 was the year when the process of democratic change began in Poland. From February 6 to April 5 there were deliberations of the Round Table ("Okrągły Stół"), attended by representatives of persons who had a political power in them hands at that time and representatives of Solidarity (Solidarność) (Zięba, 2010). After two months of difficult negotiations, a compromise was reached. The authorities decided to allow the opposition to participate in the government. The agreement concluded at the Round Table contributed to the implementation of systemic changes (Kuźniar, 2008). The victory in the June 1989 elections of representatives of the democratic opposition, centered in Solidarity, initiated systemic transformations. It was the first partly independent government formed after the end of Second World War, whose Prime Minister Tadeusz Mazowiecki interrupted the hegemony of communist influence. The coalition government began its operations on September 12, 1989 (Zięba, 2010). A new period in the history of Poland and Central and South-Eastern Europe has begun. There were also new challenges accompanying the transformation process (Rotfeld, 2003).

Polish changes in the middle of 1989 "on the Vistula River" (this is usually called the region in question), opened the chance for Poland to create new national security structures (Kuźniar, 2008). The dynamics of processes taking place then in the international arena meant that their range and consequences were unpredictable. The situation in Poland was complex. The conduct of the security policy was determined by several factors. The most important include the existence of the Eastern Bloc, the stationing of the Red Army in Poland, and the attitude of Western European countries to our country. On the threshold of changes, the scope of security policy was established within the defense doctrine signed by President Wojciech Jaruzelski (then President of Poland). This document takes into account the existing strength structure and Poland's affiliation to the Warsaw Pact. It was planned to liquidate the existing alliances and create a new system of European security.

Then Minister Krzysztof Skubiszewski was the minister of foreign affairs. For four years he led a security policy, not having much more experience in this area. He struggled with many problems (Grodzki, 2009). The implementation of the plans was hampered by the scarcity of finances and the lack of competent personnel to carry out sovereign activities. Despite these difficulties, Minister Skubiszewski led the foreign policy of independent Poland, succeeding. There were many critics of his actions who believed that the minister did not always understand the essence of the new challenges that Europe was facing.

K. Skubiszewski from the beginning of the 90's of the twentieth century dealt with re-arranging relations with neighbors. The authorities of the Third Polish Republic in the early 1990's sought solutions in which it was possible to lay the foundations for a new quality of national security. Political elites were aware that there was a unique opportunity to resolve the issue of state security, which would free Poland from the role of a hostage of foreign expansion (Kuźniar, 2001). It was emphasized that the central element of the reason of state is external security, which determines the behavior and development of the state.

The Polish side at that time considered the creation of new forms of cooperation or alliance with the Soviet Union. The support of this concept by the Solidarity (Solidarność) movement was an element of a specific tactic resulting from the then international situation. Among the political arguments that make up this kind of reasoning, Moscow's resignation 
from influence in Central Europe was not taken into account. It was believe that some form of agreement with the Soviet Union was necessary to ensure security in the new geopolitical situation. The circles of the "left side" were strongly attached to the alliance with the eastern neighbor. However, such an approach was not accepted by political circles defining the Polish security policy (Kuźniar, 2001).

The foreign policy of the government of Tadeusz Mazowiecki in the initial period of political transformation was carried out extremely carefully, especially with the Soviet Union. Minister Krzysztof Skubiszewski tried to convince the most important people in the Kreml, that he would not seek to lead Poland out of the Warsaw Pact (Układ Warszawski) and CMEA - The Council for Mutual Economic Assistance (Rada Wzajemnej Pomocy Gospodarczej - RWPG). The first foreign guest of Prime Minister Mazowiecki was Vladimir Kriuchkov - head of the KGB (Committee for State Security). The declaration submitted by Minister Skubiszewski in October 1989 during the meeting of the Committee of Ministers of Foreign Affairs of the Warsaw Treaty was to appease the Russians. He emphasized the need to democratize the Treaty and give it a more political and military character. The declarations of the Polish side were judged by Moscow as credible, which was confirmed by Foreign Minister Eduard Shevardnadze during his stay in Warsaw (Dudek, 2013).

The Soviet Union did not attach particular importance to ties with Poland. For the Kremlin authorities, the priority was to stop the collapse of the USSR (Soviet Union), as well as relations with the United States (Kuźniar, 2001). In July 1990, he convened the XXVIII Congress of the Communist Party of the Soviet Union (CPSU). The situation in this country was not stable. Already in February this year, the CPSU (Communist Party of the Soviet Union) formally renounced its monopoly on power. The following month, Articles 6 and 7 withdrew from the Constitution regarding the leadership role of the Communist Party. The Congress of People's Deputies created the office of the president and entrusted this position to Mikhail Gorbachev (Михаил Горбачев). The reforms introduced by Mikhail Gorbachev did not lead to the strengthening of the state, on the contrary - they gradually led to their disintegration. In March 1990, the Verkhovna Rada (the highest body of legislative power): Lithuania and Estonia declared independence declarations. Two months later, the Latvian Supreme Council also accepted the declaration of independence. However, these declarations were not tantamount to the occurrence of these states from the USSR, they only demonstrated the growing tendency to secession. From the end of the 1980 's, conflicts in Transcaucasia intensified. The general secretary was increasingly blamed on weakening the role of the party in the state and accepting the gradual disintegration of the superpower. In the summer of 1990, the two largest republics - Russia and Ukraine - announced declarations of sovereignty. M. Gorbachev tried to save the USSR by holding talks with representatives of ten republics about the creation of the federation. The "putsch" made on the night of 18 August 191991 by the closest associates of M. Gorbachev was to stop the process of disintegration of the USSR, but actually accelerated its disintegration (Bonusiak, 2008). 


\section{SHAPING THE SECURITY OF THE III REPUBLIC OF POLAND IN THE CONTEXT OF INTERNATIONAL CONDITIONS}

The Polish security policy was shaped in difficult conditions. Different concepts, often divergent, clashed here (Kuźniar, 2001; 2011). In the military circles, the idea of the so-called armed neutrality (Kuźniar, 2001). In Polish geopolitical conditions, the idea of neutrality was unacceptable. It would have to take into account the adoption by Poland of the strategy of defense in all possible directions, which prevented the military and economic potential of the state. This concept was not supported by the head of the Ministry of Foreign Affairs. A more attractive idea was the separation of countries on the geostrategic map of Europe that were supposed to create a block of security between East and West. This process was accompanied by a policy of conscious displaying the identity of Central Europe. However, the development of this concept was not conducive to geopolitical considerations, disputes (not only against the historical background), and above all, lack of enthusiasm for this initiative in other European countries. A lot of controversy was caused by the proposed by President Lech Wałęsa to create a NATO-bis. It assumed the establishment of a quasi-system of collective security under the leadership of NATO, composed mainly of the countries of Central Europe and Ukraine. This block of security was supposed to fill a kind of gap in this area and in the future allow many countries to enter NATO. The concept of the President of the Third Polish Republic did not find support of Minister Krzysztof Skubiszewski, nor did it gain due recognition of politicians from other countries.

In Poland, the concept of creating security on the Old Continent based on not allied grounds was considered. It was assumed that after the Cold War and the past East-West confrontation, there would be no need for NATO. In this situation, the collective security system based on the Conference on Security and Cooperation in Europe (CSCE Commission on Security and Cooperation in Europe) was to play the main role. This institution was to protect against potential threats in the sphere of security (Kuźniar 2008). In January 1990, Prime Minister Tadeusz Mazowiecki presented at the forum of the Parliamentary Assembly of the Council of Europe the directions of Polish European policy and the proposal to establish a European Cooperation Council for the states parties to the Final Act of the CSCE - Commission on Security and Cooperation in Europe. However, he did not specify its security function. This problem was presented by Minister Krzysztof Skubiszewski in the parliamentary expose, which he delivered on April 26, 1990. The Council, as a permanent political body of the CSCE, was to act through three committees, one of which was to deal with political and security problems. Krzysztof Skubiszewski emphasized that the priority of Polish foreign policy is to co-create the European security system in which the CSCE - Commission on Security and Cooperation in Europe was to play an important role. In mid-1991, he saw the formation of a new, cooperative European security system under the CSCE - Commission on Security and Cooperation in Europe, which was to secure Europe, so as not to become a gray buffer or neutral zone (Kuźniar 2008). The activity of Polish diplomacy testified to the role that the CSCE - Commission on Security and Cooperation in Europe was to play in the security policy. Although the concept of establishing the European Cooperation Council has not been implemented, it should be stressed that Poland's large contribution to building the institutional structure of the CSCE - Commission on Security and Cooperation in Europe (Kuźniar, 2001; 2008).

In the initial period of political transformation in Poland, several security concepts prevailed (Mickiewicz, 2005). Members of the parliament (deputies) from the "right side" 
thought that Poland should strive, like Hungary and Czechoslovakia, to join NATO as soon as possible. Center-right politicians supported the activities of Krzysztof Skubiszewski. Social Democrats, on the other hand, denied the sense of changing political and military alliances. Andrzej Drawicz connected with the Democratic Union pointed out that in the period of the weakness of the Soviet Union, the Polish government should not strive for Western European security guarantees, but should focus on creating new political and economic ties with the eastern neighbor, which will be beneficial for us. The Polish side was to act as a consultant in the US-West-Russia agreement. The Christian Democrat activist Andrzej Micewski believed that Polish diplomacy should focus on restoring the balance between Eastern and Western policy. He thought that this should be done as a result of recognizing the Russian state as the main power in the region and conducting the so-called policy of balancing the state of German-Russian relations and creating a European security system. This involved the transformation of NATO from the military pact into the organization of European security modeled on the CSCE - Commission on Security and Cooperation in Europe, with the possibility of military interference if security in Europe had to be secured. Politicians of the Third Republic of Poland emphasized that the resignation of Mikhail Gorbachev from the implementation of the "Brezhnev doctrine" made it possible to transfer disputes regarding European security from the political-military to the political level (Mickiewicz, 2005). They believed that during the development of new political and economic forms in Central and Eastern Europe, Soviet armed intervention would not take place. Poland, situated between the politically stabilized West and the weakened and crisis-ridden East, developed in a sense of no threat, but in the area of a reduced standard of security. Polish diplomacy attached great importance to agreements reducing the military potential in Europe and limiting the possibility of using force (Kuźniar, 2008). An important issue was the reform of the armed forces (Mickiewicz, 2005).

In December 1991 Mikhail Gorbachev officially stepped down as president of the USSR (Soviet Union). The Empire ceased to exist (Bonusiak, 2008). The disintegration of the Soviet Union in December 1991 enabled many political changes on the European continent. They have had a significant impact on the transformation of the Polish security policy (Mickiewicz, 2005). New countries arose on the rubble of the former empire, prompting Poland and the North Atlantic Alliance to determine their role in the European security system. Alliance politicians and military thought that the most important organization that can provide stability in the area is the North Atlantic Cooperation Council. However, it did not provide Central European countries with security, but only organized the possibility of consulting in the field of security, arms control and restructuring of the defense industry. The Polish side tried to define the role of the new neighbors in the security strategy. The Ministry of Foreign Affairs sought to establish partner political, economic and military contacts with them. Poland's relations with the Russian Federation were dissolved before the collapse of the Soviet Union (Zięba, 2010). However, the relations between the two countries were dominated by sources of tension, difficult to overcome (Pełczyńska-Nałęcz, 2010). The stationing of the Red Army in Poland was not conducive to the creation of new foundations for bilateral relations. An agreement on the withdrawal of troops was initialed in October 1991. This process was completed in September 1993. In the initial period of political transformation, Poland's relations with the Russian Federation were not good. There was a breakdown in economic cooperation after switching to a dollar settlement. The lack of recognition of the interdependence of interests of both countries was noticed. 
Supporting independence efforts in Poland in post-Soviet countries was interpreted by Russia as interference in the affairs of their close neighbors, as well as limiting its influence. In addition, Russia did not accept Poland's accession to NATO structures.

The Polish side attached great importance to improving relations with Germany. Prior to completing the government, Prime Minister Tadeusz Mazowiecki appointed a special representative for contacts with the German Chancellor's Office, who became Mieczysław Pszon, an expert on German issues and a proponent of the Polish-German rapprochement (Majcherek, 1999). For T. Mazowiecki, reconciliation with Germany was one of the priorities of his policy. The Minister of Foreign Affairs Krzysztof Skubiszewski sought to build reconciliation and cooperation on a good treaty basis (Kuźniar, 2008).

The visit of the German Chancellor Helmut Kohl to our country was of great importance for the Polish-German rapprochement. On November 9, 1989, the German Chancellor and Prime Minister of Poland Tadeusz Mazowiecki took part in an ecumenical mass in Krzyżowa in Lower Silesia, during which symbolic reconciliation took place. From Berlin, news reached that the GDR (German Democratic Republic) authorities agreed to cross the border by their citizens. The so-called overthrow the Berlin Wall. Chancellor Helmut Kohl interrupted his visit to Poland to participate in a historical event. After two days he returned to Warsaw to continue the conversation, in a slightly different climate (Kuźniar, 2008).

An important problem was the unification of both German countries. The government of Tadeusz Mazowiecki was the first among the Warsaw Pact countries to recognize the right of Germans to unite, with the proviso that they will not be a threat to other European countries. The Polish side did not expect a rapid unification process. Meanwhile, at the end of November 1989, a 10-point plan to overcome the division of Germany and Europe was formulated by Chancellor Helmut Kohl. It includes the creation of confederal structures by Germany and the GDR (German Democratic Republic) and, as a result, the creation of one German country. The plan did not take into account the issue, the borders on the Odra River and Nysa Łużycka River, which caused criticism from the Polish government Kuźniar, 2008). European politicians have wondered about the future of Germany. The United Kingdom and France, although supporting the unification process, did not hide some anxiety. In Moscow, the changes taking place in Germany were supported. The United States has also given adequate support to the Germans. The problem of the creation of one German state appeared in February 1990. Then the so-called group $2+4$ at the level of foreign ministers, composed of representatives of two German countries and four powers deciding the fate of Germany. Krzysztof Skubiszewski participated in the third session of the $2+4$ conference held in July 1990 in Paris. On the other hand, the final regulation treaty with regard to Germany was signed on September 12, 1990 in Moscow by the participants of the $2+4$ conference (Majcherek, 1999).

The balance of Polish - German political and pragmatic reconciliation found its treatypolitical expression in the period of overcoming the division of Europe in 1989-1991. Mutual relations, long characterized by distrust, improved considerably and had a different value. In November 1990, the Ministers of Foreign Affairs of Poland and Germany signed the Treaty on the confirmation of the existing Polish - German border. Poland was interested in the development of bilateral cooperation in various fields of mutual relations. Minister Kzysztof Skubiszewski emphasized the essence of the Polish-German community of interests. On June 17, 1991, the treaty between the Republic of Poland and the Federal Republic of Germany on good neighborliness and friendly cooperation was signed in Bonn (then the capital of Germany). He is considered by many to be a "constitution" of relations 
between Poland and unified Germany. Undoubtedly, it forms the basis of Polish - German dialogue. He outlined the fields of joint action of both countries (Wóycicki, Czachur, 2009).

\section{NATO AND THE EU IN POLISH SECURITY POLICY}

In the foreign policy of the Third Polish Republic, relations with NATO were of particular importance. Prospects for expanding the security environment created a new situation in Central and Eastern Europe (Rotfeld, 2006). They meant that the states in this region would accept all the criteria binding in the transatlantic community: political pluralism, the rules of a democratic state, respect for human rights and the rights of national minorities, respect for political liberties and media freedom. The process of expanding the Alliance and the Union was accompanied by resolving disputes between states. The "Visegrad Group" and other regional structures have been created that have played an important role. They favored stabilization and resolution of disputes and animosities rooted in the difficult history of these countries, but also prevented the recurrence of crisis situations between various countries of Central and Eastern Europe.

Poland's accession to NATO took place in the period of significant changes in the international security system (Kuźniar, 2008). They were not related to the enlargement of the Alliance or membership of Poland. Previously unfavorable phenomena and threats were revealed. Noteworthy were: terrorism motivated by the fundamentalist version of Islam, the threat of proliferation of weapons of mass destruction, and the consequences of the process referred to as "fallen and failing countries". They influenced the security strategy of the NATO and Alliance states as a whole. The new threats to international security have been for the US since 2001 a kind of justification for the ongoing renationalisation and militarization of foreign and security policy, as well as the consolidation of influence. Poland and other Alliance countries had to make difficult decisions. Politicians of the Third Polish Republic often emphasized the role of the Alliance as a guarantee of our security. However, its defensive function took on a different dimension. The Alliance focused on maintaining security not only in the neighborhood, but also far from its borders, and carried out expeditionary operations not related to art. 5 of the Washington Treaty (Banasik, 2009). The Polish side fully supported the accelerated doctrinal evolution of the Alliance and conducted military operations, although it did not participate in making appropriate decisions. Poland uncritically supported the development of Alliance expeditionary tasks and actively supported American activities.

Membership in NATO brought specific tasks to Poland in the area of development and modernization of the armed forces, as well as foreign policy (Kuźniar, 2008). Together with NATO, the objectives of the armed forces for Poland were agreed, the infrastructure was adapted to the requirements of cooperation and our country was included in the Alliance defense system. Actions have also been taken to implement standards for the protection of classified information that would ensure the functionality of the defense system with NATO forces. Integration with the Alliance has changed the security environment of our country and influenced the quality changes in the armed forces (Gagor, 2009).

NATO secures Poland against the so-called traditional threats. However, it must be remembered that the Alliance can not be the disarming myth that Maginot Line has become for France in the interwar period - the most powerful system of fortifications ever built along the entire French border with Germany (Nowak-Jeziorański, 2003). This system created a false sense of security. The French have neglected preparations for military 
operations, they have not drawn the right conclusions from the World War One. The Germans circled and defeated the Maginot Line. The pogrom of France, then military power, is an eloquent warning and prompts deep reflection.

Poland entering the European Union obtained additional guarantees of its security. Politicians from the Third Polish Republic in the first half of the nineties paid attention to this aspect. However, after joining the EU, the situation has changed (Kuźniar, 2006). The Polish side tried to delay the Union's maturation to this important role, probably not to limit the importance of NATO or the position of the United States. Polish politicians, bearing in mind national interest, should remember the United States' crisis caused by the United States against the background of the Iraq war and the consequences (Zięba, 2007). Americans have a tendency to pursue a policy that may pose a threat to other Western countries as well as their allies. Misunderstandings arising in connection with the Iraq crisis made it difficult for the European Union and the United States to find solutions to many difficult problems (Zięba, 2007). Robert Kagan emphasized that "Americans are idealists, but they have no experience in effectively promoting ideals without using force" (Słomczyńska, 2007). Their actions boil down to attack, but this does not mean commitment. They lack coherence: diplomacy, military strength and development support. In this respect, there are differences between the European Union and the US. American policy is "militarized" and, in turn, "uncivilized" by the Union (Słomczyńska 2007).

The European Union is constantly looking for its place and role on the international political scene (Parzymies, 2009). This applies to both the prevention of all kinds of threats and the form of relations with recognized world powers. As a hybrid international structure, the Union is constantly being transformed at a functional level, which is impacted by the Member States (Słomczyńska, 2007). NATO and the European Union can complement each other (Łastawski, 2009). NATO is a political and strategic alliance with military structures. The European Union, on the other hand, is an international community embracing the whole of life of states and nations. It should be noted that the European Union's security policy covers more areas than NATO's political and military activities.

The priority of Polish diplomacy should be to take a strong position in the EU and to search for appropriate partners for cooperation. Minister Radosław Sikorski in the parliamentary expose of May 8, 2008 drew attention to the need for the peaceful integration of Europe (Łastawski, 2009). The European Union creates a Common Foreign and Security Policy and the European Security and Defense Policy. The Polish side, taking into account the security interest, should effectively cooperate with other Member States in this regard. It should also support the development of the EU's crisis response capability. Creating safe conditions for the development of Poland is in line with the objectives of the European Union's foreign and security policy.

\section{CONCLUSION}

In addition to alliances and security communities, bilateral relations, especially with neighbors, are very important. None of them challenges our borders. This is undoubtedly an unprecedented situation in the history of Poland. Our independence is not threatened. We are sovereign in the modern sense of the term. Although it was not possible to establish friendly relations with all neighbors, the matter of borders was finally settled. The existing threats to our sovereignty are not related to traditionally understood security, but are the 
result of global economic processes. However, the European security situation is not comfortable. International terrorism and its derivatives, so-called asymmetric threats are dangerous phenomena.

\section{REFERENCES}

Banasik, M. (2009). Ewolucja ekspedycyjności NATO w latach 1989-2001. „Kwartalnik Bellona" nr 1.

Bonusiak, W. (2008). Trzecia Rzeczpospolita (1989-2007). Rzeszów: Wydawnictwo UR.

Gągor, F. (2009). Dziesięć lat w NATO. „Kwartalnik Bellona” nr 1.

Grodzki, R. (2009). Polska polityka zagraniczna w XX i XXI wieku. Gtówne kierunki-FaktyLudzie - Wydarzenia. Zakrzewo: Wydawnictwo Replika.

Koćwin, L. (1992). Dekada przełomu. Stosunki polsko-niemieckie od czerwca 1989 do czerwca 1991. Dokumenty. Materiały. Komentarze. Wrocław.

Koszel, B., Malinowski, K., Mazur, Z. (2012). Niemiecka polityka wobec Polski 1990-2010. Poznań: Instytut Zachodni.

Kuźniar, R. (2008). Droga do wolności. Polityka zagraniczna III RP. Warszawa.

- (2016). Europa w porządku międzynarodowym. Warszawa: PISM.

red. (2001). Polska polityka bezpieczeństwa 1989-2000. Warszawa: Wydawnictwo Naukowe SCHOLAR.

Madera, A.J. (2003). Polska polityka zagraniczna. Europa Środkowo-Wschodnia 1989-2003. Kraków: Firma „Sas” Wanda Tarnawska.

Majcherek, J.A. (1999). Pierwsza dekada III Rzeczypospolitej. Warszawa: Wyd. Rzeczpospolita.

Mickiewicz, P. (2005). Polska droga do NATO. Implikacje polityczne i wojskowe. Toruń: Wydawnictwo Adam Marszałek.

Modzelewski, W.T., red. (2009). Polska wobec sqasiadów. Wspótczesne stosunki polityczne. Olsztyn: Wydawnictwo INP UWM.

Nowak-Jeziorański, J. (2003). Kryteria bezpieczeństwa [w:] Dębski, S., Górka-Winter, B., red., Kryteria bezpieczeństwa międzynarodowego państwa. Warszawa: Wydawca: Polski Instytut Spraw Międzynarodowych Wydział Wydawnictw MSZ.

Pełczyńska-Nałęcz, K. (2010). Stosunki polityczne między Polska a Rosja po 1990 r. [w:] Rotfeld, A.D., Torkunow, A.W., red., Biate plamy - czarne plamy. Sprawy trudne w polsko-rosyjskich stosunkach 1918-2008. Warszawa: PISM.

Rotfeld, A.D. (2006). Polska w niepewnym świecie. Warszawa: PISM.

Stokwiszewski, D. (2014). Ewolucja polityki zagranicznej i obronnej Rzeczypospolitej Polskiej w ramach euroatlantyckiego systemu bezpieczeństwa w latach 1999-2013. Warszawa: AON.

Wojtaszczyk, K.A., Materska-Sosnowska, A., red. (2009). Bezpieczeństwo państwa. Wybrane problemy. Warszawa: Wydawca: Oficyna Wydawnicza ASPRA-JR.

Wóycicki, K., Czachur, W. (2009). Wyzwania polskiej polityki wobec Niemiec. „Sprawy Międzynarodowe” nr 1.

Zenderowski, R., Koziński, B. (2015). Uwarunkowania polityki zagranicznej Rzeczypospolitej Polskiej. Warszawa: Wydawnictwo UKSW.

Zięba, R. (2010). Główne kierunki polskiej polityki zagranicznej po zimnej wojnie. Warszawa: Wydawnictwa Akademickie i Profesjonalne. 
Żurawski vel Grajewski, P. (2012). Bezpieczeństwo międzynarodowe. Wymiar militarny. Warszawa: Wydawnictwo Naukowe PWN.

(2016). Polska polityka wschodnia 1989-2015. Wymiar narodowy i unijny. Kraków: OMP.

DOI: $10.7862 /$ rz.2020.hss.2

The text was submitted to the editorial office: February 2020.

The text was accepted for publication: March 2020. 